\title{
Effect of Co/Sn Doping on the Thermal Stability of Magnetic Properties of Ba-Ferrite
}

\author{
Thin Films \\ Chih-Ming Kuo, P. C. Kuo and Yung-Yuan Wu \\ Institute of Materials Science and Engineering, National Taiwan University, Tạipei, Taiwan \\ J. W. Chen \\ Department of Physics, National Taiwan University, Taipei, Taiwan
}

\begin{abstract}
BaFe ${ }_{12-2 \mathrm{x}} \mathrm{Co}_{\mathrm{x}} \mathrm{Sn}_{\mathrm{x}} \mathrm{O}_{19}$ (where $\mathrm{x}=0 \sim 1.03$ ) thin films were made by $\mathrm{rf}$ magnetron sputtering in $\mathrm{Ar}-\mathrm{O}_{2}$ mixed atmosphere. These films were then post-annealed in air between $850^{\circ} \mathrm{C}$ and 1000 ${ }^{\circ} \mathrm{C}$ for 10 minutes, in order to get $\mathrm{M}$-type phase. The contents of $\mathrm{Co} / \mathrm{Sn}$ on the magnetic properties and thermal stability of the magnetic properties of the films were discussed.
\end{abstract}

\section{INTRODUCTION}

Recently, there has been interested in using thin film BaM for high density magnetic recording media, because it possess not only excellent magnetic properties but also has good mechanical and chemical stability. Sputtered Ba-ferrite thin films under normal conditions are amorphous structure in nature and they are nonmagnetic [1]. Hence, crystalline BaM thin films have to be obtained by either applying in-situ substrate heating during deposition [2] or through a postdeposition annealing treatment [3].

Many investigators [4-6] indicate that $\mathrm{Co} / \mathrm{Ti}$ doped $\mathrm{BaM}$ particles could reduce grain size of the particles. However, their temperature coefficient of coercivity $\mathrm{dHc} / \mathrm{dT}$ is about $+3 \sim+40 \mathrm{Oe} /{ }^{\circ} \mathrm{C}$ [7]. Kubo et al. [7] have substituted various third elements into the Ba-ferrite particles. They found that $\mathrm{Sn}$ is the most effective element in reducing $\mathrm{dHc} / \mathrm{dT}$ of the particles. $\mathrm{Li}$ and Sinclair [8] found that temperature coefficient of coercivity $\mathrm{dHc} / \mathrm{dT}$ of the $\mathrm{Ti} / \mathrm{Zn}$ doped BaM thin film is about $+0.5 \mathrm{Oe} /{ }^{\circ} \mathrm{C}$ for perpendicular coercivity and $30 \mathrm{e} /{ }^{\circ} \mathrm{C}$ for in-plane coercivity.

In this report, we investigate the effect of $\mathrm{Co} / \mathrm{Sn}$ doping on the thermal stability of the magnetic properties of the BaM films. The effects of $\mathrm{Co} / \mathrm{Sn}$ contents and annealing temperature on the perpendicular and in-plane magnetic properties of the $\mathrm{Co} / \mathrm{Sn}$ doped $\mathrm{BaM}$ thin films were also examined.

\section{EXPERIMENT}

$\mathrm{BaFe}_{12-2 x} \mathrm{Co}_{x} \mathrm{Sn}_{x} \mathrm{O}_{19}($ where $\mathrm{x}=0 \sim 1.03)$ thin films were made by rf magnetron sputtering system in the $\mathrm{Ar}-\mathrm{O}_{2}$ mixed

Manuscript received June 30, 1997.

Chih-Ming Kuo, 886-2-363-0231-3399, fax 886-2-363-4562, f3508035 (a)cc.ntu.edu.tw; P. C. Kuo, 886-2-363-0231-3038, pckuo@ccms.ntu.edu.tw

This work was supported by the National Science Council of ROC through Grant No. NSC 86-2216-E 002-029. atmosphere, then post-annealed in air between $850^{\circ} \mathrm{C}$ and $1000^{\circ} \mathrm{C}$ for 10 minutes. $\mathrm{Co} / \mathrm{Sn}$ doped BaM targets were used in this experiment. All of the films were deposited onto a room-temperature fused silica glass substrate. The base pressure in the system was $1 \times 10^{-5}$ Torr, and after the high purity $\mathrm{Ar}-\mathrm{O}_{2}$ mixed gas ( $\mathrm{Ar}: \mathrm{O}_{2}=9: 1$ ) was introduced, sputtering pressure was $5 \times 10^{-3}$ Torr. Thickness of the films was $100 \mathrm{~nm}$.

The structure and phase types of the films were determined by using $x$-ray diffractometer (XRD). Magnetic properties of the films were measured with vibrating sample magnetometer (VSM) at room temperature with maximum applied field of $12 \mathrm{kOe}$. Composition and homogeneity of the films were determined by energy disperse $x$-ray spectrometer (EDS). Thickness of the films was measured by a $\alpha$-step.

\section{RESULTS AND DISCUSSION}

Figure 1 shows the coercivity $\mathrm{Hc}$ and saturation magnetization $\mathrm{Ms}$ of the $\mathrm{BaFe}_{12-2 \mathrm{x}} \mathrm{Co}_{\mathrm{x}} \mathrm{Sn}_{\mathrm{x}} \mathrm{O}_{19}$ thin films as a function of $\mathrm{Co} / \mathrm{Sn}$ content $\mathrm{x}$. These films were post-annealed at $950^{\circ} \mathrm{C}$ for 10 minutes in air. It can be seen that both the out-plane coercivity $\mathrm{Hc}_{\perp}$ and in-plane coercivity Hal decrease dramatically with increasing $x$ while the saturation magnetization Ms decreases slowly with increasing $\mathrm{x}$. For pure $\mathrm{BaM}$ film, its $\mathrm{Hc}_{\perp}$ is about $3200 \mathrm{Oe}, \mathrm{Ha}$ is about 2200 $\mathrm{Oe}$, and $\mathrm{Ms}$ is about $320 \mathrm{emu} / \mathrm{cm}^{3}$. As $\mathrm{x}$ is increased to 0.83 , they decrease to about $1100 \mathrm{Oe}, 850 \mathrm{Oe}$, and $240 \mathrm{emu} / \mathrm{cc}$, respectively for $x=0.83$. The out-plane coercivity always higher than that of in-plane for the same $x$. The increasing of $\mathrm{Co} / \mathrm{Sn}$ content $\mathrm{x}$ will suppress the out-plane coercivity more than that of the in-plane coercivity. Hence, we can get nearly magnetic isotropy $\mathrm{BaM}$ thin films (i.e., $\mathrm{Hc}_{\downarrow} \cong \mathrm{Hcl}$ ) by doping proper amount of $\mathrm{Co} / \mathrm{Sn}$.

The magnetic moment of Ba-ferrite unit cell is coming from the resultant moment of $\mathrm{Fe}^{3+}$ ions at spin-up $(12 \mathrm{k}, 2 \mathrm{~b})$ and spin-down $\left(4 f_{2}\right)$ sites [9]. The decrease of $M s$ value with increasing $\mathrm{x}$ is due to that the substitution of these magnetic $\mathrm{Fe}^{3+}$ ions with nonmagnetic $\mathrm{Sn}^{4+}$ ions. On the other hand, the $\mathrm{Fe}^{3+}$ ions at $12 \mathrm{k}$ and $2 \mathrm{~b}$ sub-lattices are major contributors to the overall uniaxial anisotropy of $\mathrm{BaM}$ ferrite [10]. The substitution of $\mathrm{Fe}^{3+}$ ions with $\mathrm{Co}^{2+}$ and $\mathrm{Sn}^{4+}$ ions at $12 \mathrm{k}$ and $2 \mathrm{~b}$ 
sites will destroy the exchange interaction between adjacent $12 \mathrm{k}$ and $2 \mathrm{~b}$ sites and reduce the coercivity of BaM .

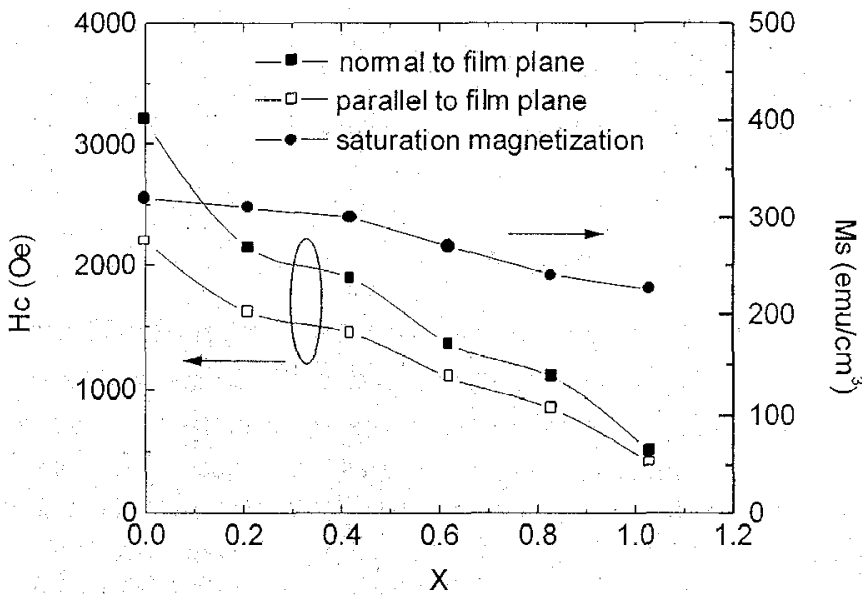

Fig. 1. Coercivities and the saturation magnetization $M s$ as function of $\mathrm{Co} / \mathrm{Sn}$-doping $x$ for the $\mathrm{BaFe}_{12-2 x} \mathrm{Co}_{x} \mathrm{Sn}_{x} \mathrm{O}_{19}$ thin films. These films were post-annealed at $950^{\circ} \mathrm{C}$ for 10 minutes in air.

Figure 2 shows the variation of $\mathrm{Ms}$ with temperature between $20^{\circ} \mathrm{C}$ and $100^{\circ} \mathrm{C}$ for various $\mathrm{BaFe}_{12-2 x} \mathrm{Co}_{\mathrm{x}} \mathrm{Sn}_{\mathrm{x}} \mathrm{O}_{19}$ thin films. It is obviously that the value of Ms decreases with increasing temperature. In figure 2 , we can see that the slope of Ms vs. T curve is decreased with increasing $\mathrm{x}$. This is due to that the variation of Ms with temperature is dominated by the interactions of $12 \mathrm{k}-2 \mathrm{a}$ ions and $12 \mathrm{k}-12 \mathrm{k}$ ions for small $\mathrm{x}$ $(\mathrm{x}=0 \sim 0.42)$. But, it is dominated by the perturbing effect of $12 \mathrm{k}-2 \mathrm{~b}$ interaction for larger $\mathrm{x}(\mathrm{x}=0.62 \sim 1.02)[11]$.

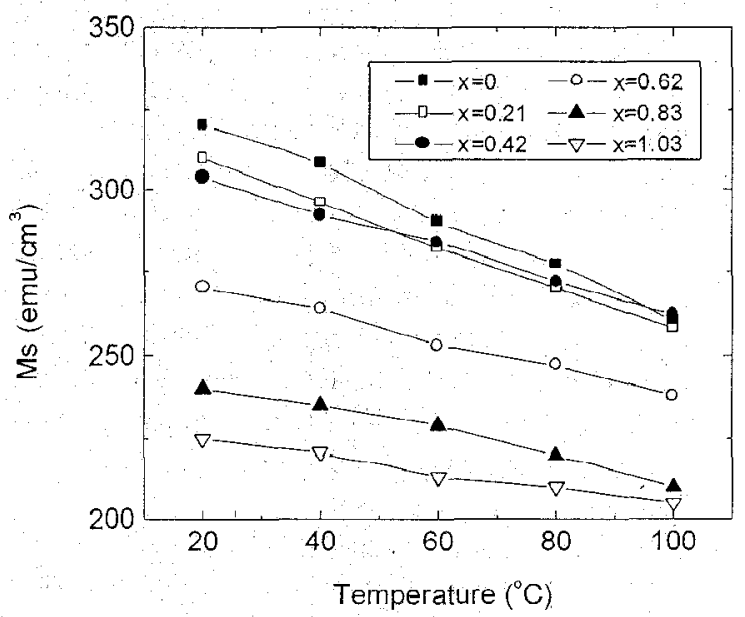

Fig. 2. The Ms value of $\mathrm{BaFe}_{12-2 \mathrm{x}} \mathrm{Co}_{\mathrm{x}} \mathrm{Sn}_{x} \mathrm{O}_{19}$ thin films as function of temperature between $20^{\circ} \mathrm{C}$ and $100^{\circ} \mathrm{C}$.

The temperature coefficient of coercivity, defined by $\mathrm{dHc} / \mathrm{dT}$, was determined as $\mathrm{dHc} / \mathrm{dT}=\left[\mathrm{Hc}\left(100^{\circ} \mathrm{C}\right)-\mathrm{Hc}(20\right.$ $\left.\left.{ }^{\circ} \mathrm{C}\right)\right] / 80^{\circ} \mathrm{C}$. Where $\mathrm{Hc}\left(100^{\circ} \mathrm{C}\right)$ and $\mathrm{Hc}\left(20^{\circ} \mathrm{C}\right)$ are the coercivities at $100^{\circ} \mathrm{C}$ and $20^{\circ} \mathrm{C}$, respectively the values of $\mathrm{dHc} / \mathrm{dT}$ as a function of $\mathrm{x}$ for the $\mathrm{BaFe}_{12-2 \mathrm{x}} \mathrm{Co}_{\mathrm{x}} \mathrm{Sn}_{\mathrm{x}} \mathrm{O}_{19}$ thin films are plotted in figure 3 . These curves indicate that both in-plane and out-plane coercivities are increased with increasing temperature for $\mathrm{x}: 00.62$, and decreased with increasing temperature for $x>0.62$. The dashed line indicates that the coercivity is not affected by the temperature. The outplane $\mathrm{dHc} / \mathrm{dT}$ of the film is decreased from +4.2 to $-1.3 \mathrm{Oe}$ ${ }^{\circ} \mathrm{C}$, and out-plane $\mathrm{dHc} / \mathrm{dT}$ decreases from +4.8 to -1.1 , as $\mathrm{x}$ increase from 0 to 1.03 . For $x=0.62$, the values of out-plane and in-plane $\mathrm{dHc} / \mathrm{dT}$ are $0.10 \mathrm{e} /{ }^{\circ} \mathrm{C}$ and $0.20 \mathrm{e}^{\circ} \mathrm{C}$, respectively.

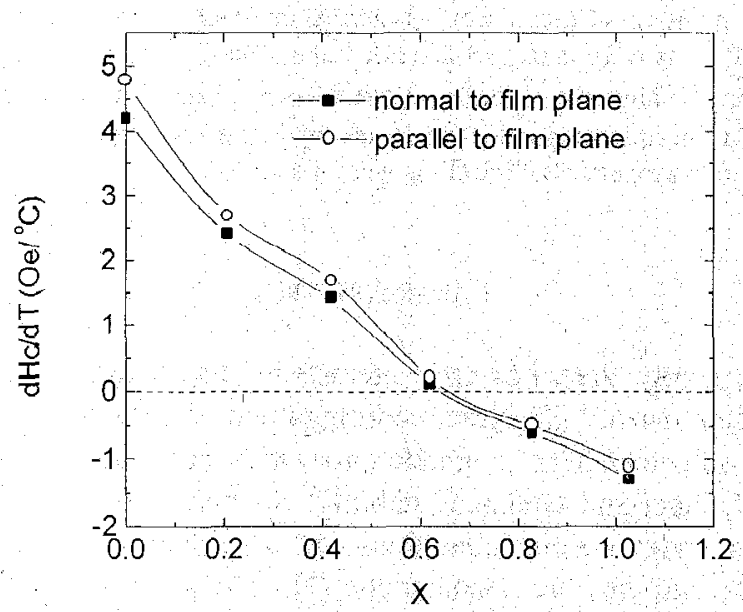

Fig. 3. The temperature coefticient of coercivity $\mathrm{dHc} / \mathrm{dT}$ as function of $\mathrm{x}$ for various $\mathrm{BaFe}_{12-2 \mathrm{x}} \mathrm{Co}_{\mathrm{x}} \mathrm{Sn}_{\mathrm{x}} \mathrm{O}_{19}$ thin films.

Figure 4 shows $X$-ray diffraction patterns of the $\mathrm{BaFe}_{10.76} \mathrm{Co}_{0.62} \mathrm{Sn}_{0.62} \mathrm{O}_{19}$ films which annealed at temperatures between $850^{\circ} \mathrm{C}$ and $1000^{\circ} \mathrm{C}$ for 10 minutes in order to avoid grain growth. It reveals that completely M-type Ba-ferrite can be obtained when the annealing temperature $T_{A}$ is higher than $950^{\circ} \mathrm{C}$. As $T_{A}$ is lower than $900^{\circ} \mathrm{C}$, we can see that there has nonmagnetic $\alpha-\mathrm{Fe}_{2} \mathrm{O}_{3}$ phase appeared.

Figure 5 shows the variations of $\mathrm{Hc}$ and $\mathrm{Ms}$ of the $\mathrm{BaFe}_{10.76} \mathrm{Co}_{0.62} \mathrm{Sn}_{0.62} \mathrm{O}_{19}$ thin film with annealing temperature between $850^{\circ} \mathrm{C}$ and $1000^{\circ} \mathrm{C}$. Ms is increased with annealing temperature $T_{A}$ and the increase of Ms becomes slowly as $T_{A}$ $>950^{\circ} \mathrm{C}$. Hc is also increased with $T_{A}$ as $T_{A}$ is lower than 950 ${ }^{\circ} \mathrm{C}$, but it decreases when $T_{A}$ is higher than $950^{\circ} \mathrm{C}$. When $T_{A}$ $<950^{\circ} \mathrm{C}$, the increase of $\mathrm{Ms}$ and $\mathrm{Hc}$ with $\mathrm{T}_{\mathrm{A}}$ is due to the decrease of nonmagnetic amorphous phase and $\alpha-\mathrm{Fe}_{2} \mathrm{O}_{3}$ phase as shown in Fig. 4 As $T_{A}$ is higher than $950^{\circ} \mathrm{C}$, the decrease of $\mathrm{Hc}$ is due to rapid grain growth of the film, as shown in figure 6 . Figure 6 shows the variation of average grain size of the $\mathrm{BaFe}_{10.76} \mathrm{Co}_{0.62} \mathrm{Sn}_{062} \mathrm{O}_{19}$ thin film with $\mathrm{T}_{\mathrm{A}}$. It can be seen that the average grain size increases slowly from $12 \mathrm{~nm}$ to $20 \mathrm{~nm}$ when $\mathrm{T}_{A}$ is increased from $850^{\circ} \mathrm{C}$ to $950^{\circ} \mathrm{C}$, and it increases rapidly as $T_{A}>950^{\circ} \mathrm{C}$. The average grain size was calculated from scherrer formula [12] with halfmaximum peak width of the main peak (008) in figure 4 . 


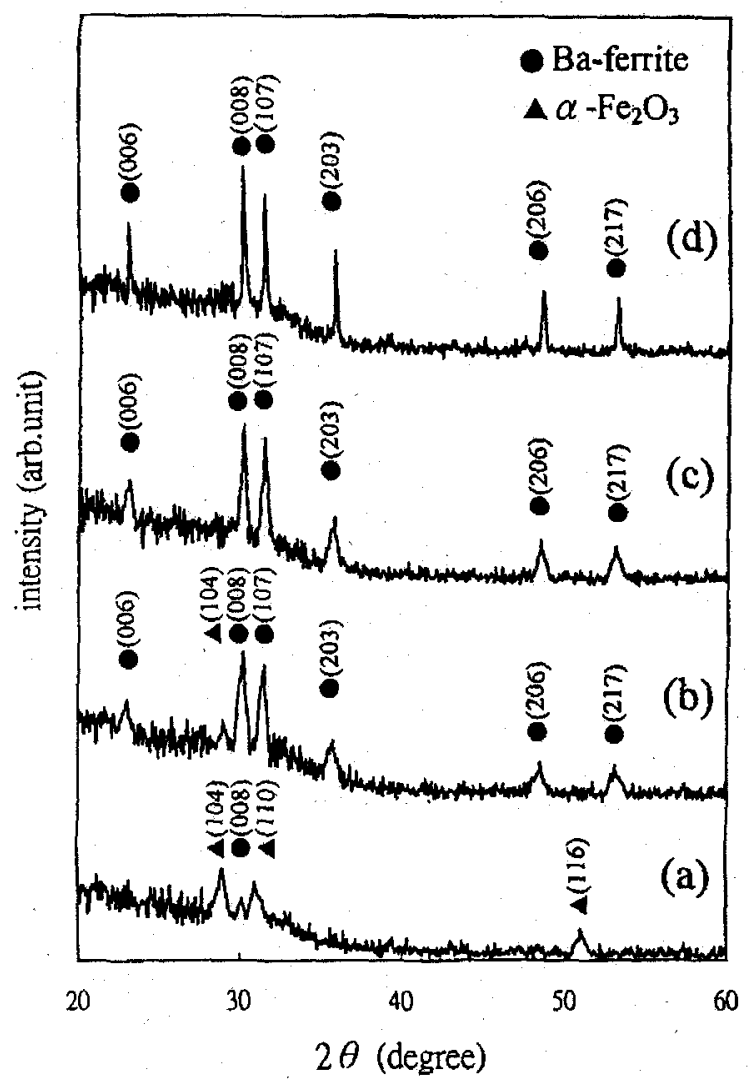

Fig. 4. X-ray diffraction patterns of the $\mathrm{BaFe}_{10.76} \mathrm{Co}_{0.62} \mathrm{Sn}_{0.62} \mathrm{O}_{19}$ thin films which are annealed at various temperatures: (a) $850^{\circ} \mathrm{C}$; (b) $900^{\circ} \mathrm{C}$; (c) $950^{\circ} \mathrm{C}$; (d) $1000^{\circ} \mathrm{C}$.

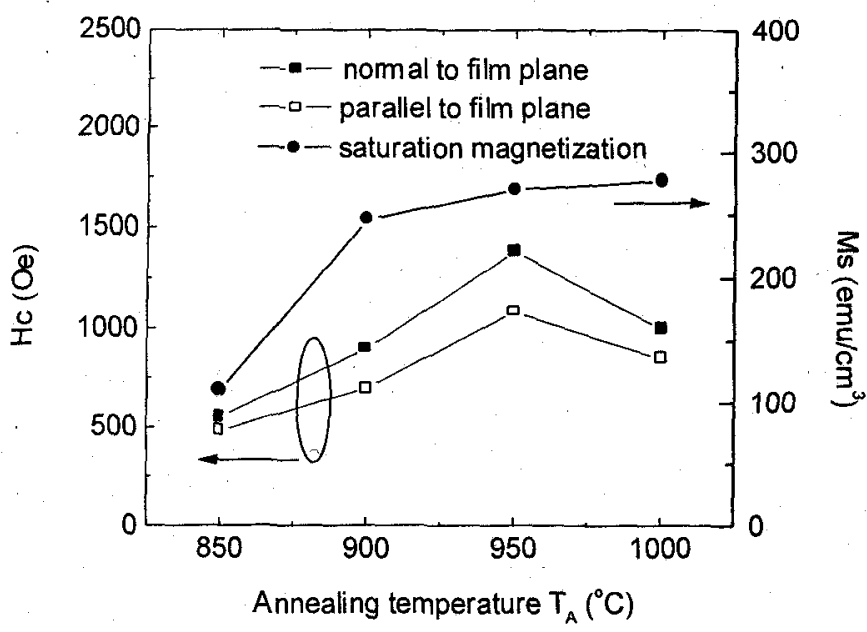

Fig. 5. Coercivities and the saturation magnetization as function of annealing temperature for the $\mathrm{BaFe}_{10.76} \mathrm{Co}_{0.62} \mathrm{Sn}_{0.62} \mathrm{O}_{19}$ thin films. These films were postannealed for 10 minutes in air.

\section{CONCLUSION}

The $\mathrm{Co} / \mathrm{Sn}$ doped barium ferrite (BaM) thin films had been prepared by using rf magnetron sputtering. $\mathrm{Ms}, \mathrm{Hc}$ and $\mathrm{Hc} \|$ of the film was decreased with increasing $\mathrm{Co} / \mathrm{Sn}$ concentration. For the $\mathrm{BaFe}_{10.76} \mathrm{Co}_{0.62} \mathrm{Sn}_{0.62} \mathrm{O}_{19}$ thin film, both in-plane and out-plane coercivities almost keep constant with temperature between $20^{\circ} \mathrm{C}$ and $100{ }^{\circ} \mathrm{C}$. Its out-plane coercivity is about $1400 \mathrm{Oe}$ and in-plane coercivity is about $1100 \mathrm{Oe}$. The saturation magnetization $\mathrm{Ms}$ is about 270 $\mathrm{emu} / \mathrm{cm}^{3}$ and the average grain size is about $20 \mathrm{~nm}$. It reveals that this $\mathrm{BaFe}_{10.76} \mathrm{Co}_{0.62} \mathrm{Sn}_{0.62} \mathrm{O}_{19}$ thin film has excellent magnetic thermal stability.

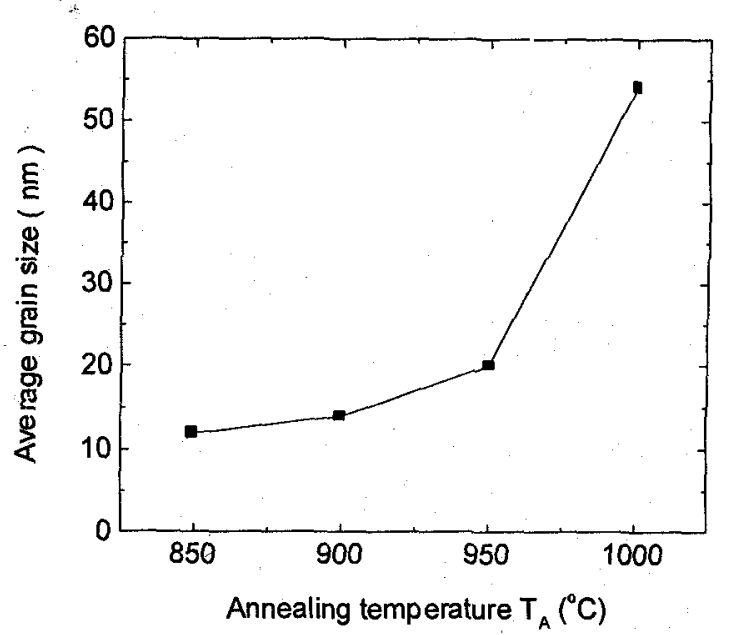

Fig. 6. Average grain size as function of annealing temperature for the $\mathrm{BaFe}_{10.76} \mathrm{Co}_{0.62} \mathrm{Sn}_{0.62} \mathrm{O}_{19}$ thin films. These films were post-annealed at $850^{\circ} \mathrm{C}$ $\sim 1000^{\circ} \mathrm{C}$ for 10 minutes in air.

\section{REFERENCES}

[1] Akimitsu Morisako, Mitsunori Matsumoto, and Masahiko Naoe, "Crystallographic and Recording Characteristics of Post-Annealed Ba-Ferrite Sputtered Films," IEEE Trans. on Magn., vol. 32, No. 5, pp. 3819-3821, 1996

[2] M. Naoe, S. Hasunuma, Y. Hoshi, and S. Yamanaka, "Preparation of Barium Ferrite Films with Perpendicular Magnetic Anisotropy by DC Sputtering," IEEE Trans. on Magn., vol. 17, No. 6, pp. 3184-3186, 1981

[3] T. L. Hylton et al., "Ba-ferrite Thin-film Media for High-density Longitudinal Recording," J. Appl. Phys. 75 (10), pp. 5960-5965, 1994

[4] M. Matsuoka, Y. Hoshi, M. Naoe, and S. Yamanaka, "Formation cf Ba-ferrite Films with Perpendicular Magnetization by Target-Facing Type of Sputtering," IEEE Trans. on Magn., vol. 18, No. 6, pp. 1119 1121,1982

[5] M. Matsuoka, and M. Naoe, "Ba-ferrite Thin- film disk for Perpendicular Magnetic Recording," J. Appl. Phys. 57 (1), pp. 40404042,1985

[6] A. Morisako and M. Matsumoto, "Sputtered Hexagonal Ba-ferrite Films for High-Density Magnetic Recording Media," J. Appl. Phys. $79(8)$, pp. $4881-4883,1996$

[7] O. Kubo, T. Nomura, T. Ido, and H. Yokoyama, "Improvement in the Temperature Coefficient of Coercivity for Barium Ferrite Particles," IEEE Trans. on Magn., vol. 24, no. 6, pp. 2859-2861, 1988

[8] Jinshan $\mathrm{Li}$ and Robert Sinclair, "Temperature and Orientation Effects on the Magnetic Properties of Doped Barium Ferrite Thin Films," IEEE Trans. on Magn., vol. 30, no. 6, pp. 4050-4052, 1994

[9] Q. A. Pankhurst et al., "Cation Distribution in Co-Ti Substitued Barium Ferrite," Prceedings ICF-5, India, pp. 323-327, 1989

[10] A.R. Corradi, et al. "Effect of The Cation Site Occupancy on The Magnetization Reversal Mechanism of Hydrothermal Barium Ferrites," IEEE Trans. on Magn., vol. 24, No. 6, pp. 2862-2864, 1988

[11] G.Albanese,M.Carbucichio,and A. Deriu, "Temperature Dependence of the Sublattice Magnetizations in Al- and Ga-Substituted M-Type Hexagonal Ferrites," Phys. Stat. Sol. (a) 23, pp. 351 -358, 1974

[12] B. D. Cullity, Elements of X-Ray Diffraction -- second edition Addison-Wesley publishing company, p. 102, 1978 